Ülger, K. (2018). The role of art education on the creative thinking skills of students in music and visual arts education: A comparison from the perspective of the music education. Abant Izzet Baysal Üniversitesi Eğitim Fakültesi Dergisi, 18 (2), 1175-1195.

Geliş Tarihi: 03/02/2017

Kabul Tarihi: 19/02/2018

\title{
THE ROLE OF ART EDUCATION ON THE CREATIVE THINKING SKILLS OF STUDENTS IN MUSIC AND VISUAL ARTS EDUCATION: A COMPARISON FROM THE PERSPECTIVE OF THE MUSIC EDUCATION
}

\author{
Kani ÜLGER*
}

\begin{abstract}
There have many views in the related literature that the art develops the creativity. Although there have been study findings on this issue regarding the Visual Arts Education, a few study findings have been existed for the Music Education. Also, there has not been any consensus on the topic that Music Education (or Visual Arts) develops the creative thinking more (or less). This study aimed to investigate whether there was a potential source of developmental differences between music students (Grade 9 and 12) and visual arts (Grade 12) students' creative thinking skills in high school education level. This study includes two folds research designs as cross-sectional and causal-comparative. As a result, it was found that music or visual arts education disciplines do not possess a privilege role in the development of the students' creative thinking skills except originality. Thus, it was concluded that overall creative thinking skills can be synonymous as gain of educational outcomes regarding to art education disciplines, but the Originality can be main educational gain of the music learning.
\end{abstract}

Keywords: Music education, visual arts education, creative thinking, originality, music improvisation

\section{SANAT EĞITIMININ MÜZIK VE GÖRSEL SANATLAR ÖĞRENIMİ GÖREN ÖĞRENCILERIN YARATICI DÜŞÜNME BECERILLERİ ÜZERINDEKİ ROLÜ: MÜZİK EĞiTiMì AÇISINDAN BİR KARŞILAŞTIRMA}

\section{ÖZET}

Sanatın yaratıcılığı geliştirdiği ile ilgili olarak alan yazında pek çok görüş bulunmaktadır. Bu konu hakkında Görsel Sanatlar Eğitimi ile ilgili bazı çalışma bulguları bulunmasına karşın, Müzik Eğitimi ile ilgili olarak çok az çalıșma bulgusu mevcuttur. Ayrıca, Müzik Eğitimi'nin (veya Görsel Sanatlar Eğitimi'nin) yaratıcı düşünceyi daha fazla (veya daha az) geliştirdiği konusunda bir görüş birliği bulunmamaktadır. Bu çalışma, müzik ve görsel sanatlar eğitiminin lise düzeyinde öğrencilerin yaratıcı düşünme becerilerinin gelişimleri açısından potansiyel bir farklılık kaynăğ olup olmadığını araştırmayı amaçlamıştır. Bu çalışmada müzik öğrencileri ile resim öğrencileri yaratıcı düşünme becerileri açısından karşılaştırılmıştır. Bu nedenle grupiçi (Müzik 9. ve 12. Sınıf) ve gruplararası (Müzik 12. Sınıf ve Görsel Sanatlar 12. Sınıf) olmak üzere iki karşılaştırma yapılmıştır. Sonuç olarak Müzik ya da Görsel Sanatlar Eğitiminin bu eğitimleri alan öğrencilerin genel anlamda yaratıcı düşünme beceri karşılaştırması açısından birbirlerinden farklı olarak ayrıcalıklı bir konuma sahip olmadıkları bulunmuştur. Ancak çalışmanın diğer sonucuna göre, yaratıcı düşünme bileşenlerinden Orijinallik (yenilikçilik) alt boyutunda müzik eğitiminin bu eğitimi alan öğrencilerin Orijinal düşünme gelişiminde olumlu yönde önemli bir rolünün olduğu bulunmuştur. Buna göre, müzik ve resim sanat disiplinlerinin Müzik ve Görsel Sanatlar Eğitimleri açısından yaratıcı düşünmenin gelişmesinde orijinallik hariç benzer rollere sahip olduğu yargısına varılmıştır.

Anahtar Kelimeler: Müzik eğitimi, görsel sanatlar eğitimi, yaratıcı düşünme, orijinallik, müzik doğaçlama

* Dr. Öğr. Üyesi, Cumhuriyet Üniversitesi, Eğitim Fakültesi, Güzel Sanatlar Eğitimi

Bölümü/Resim İşEğitimi Anabilim Dalı, kulger@gmail.com 


\section{INTRODUCTION}

As a common view, it is accepted that art is correlated to creativity. According to Runco (2014), the art is an unambiguous creative domain. Also, some previous study findings were supported this common view that the art enhances the creativity of individual (Miga, Burger, Hetland, \& Winner, 2000) in both terms of music (Coulson \& Burke, 2013) and visual arts (Rostan, 2005). This situation was also broadened toward art education (Gombrich, 1991). As a common acceptance, it can be said that the creativity is correlated with the music and the visual arts education (e.g., drawings and paintings) more than other educational disciplines (Newton \& Beverton, 2012). In terms of the Music Education, creative thinking is a performance that should be nurtured in music classrooms (Hickey \& Webster, 2001). Perhaps, it can be said that this situation is based on a valid reason regarding learning activities in art education. We can exemplify this subject by considering that the art education presents more opportunities for students to apply new techniques with an ideal learning environment to explore the unknown things within learning activities. DeLorenzo (1989) stated that exploratory experiences promote students in terms of higher levels of musical thinking. In this context, the musical performance is the new and innovative (Campbell, 1990).

As regarding to the aspect of the visual arts, it was found that drawing skills were highly correlated with the originality (Kozbelt, 2004). Also, Kerr and McKay (2013) stated that if a student possesses the ability to visualize in mind with technical skill, it is expected s/he may have become excellent in art. This situation is the most important in terms of indicating a transformation from the abstract thinking toward the concrete things by the drawing. On the other hand, Guilford stated that transformation abilities increase students' flexibility in thinking which leads to the construction of more new and creative ideas. According to him, the transformation of information is also a key to understand the insight happening in convergent and divergent productions (Fasko, 2001). Owing to the visual arts are based predominantly on the transformation ability of the abstract thinking toward the concrete things, the area of the visual arts is related to produce new outcomes. As Hickey and Webster (e.g., 2001) emphasized, musical performance as well indicates the creativity in the music learning. Kleinmintz, Goldstein, Mayseless, Abecasis, and Tsoory (2014) stated that improvisation in the music area may have effect on the creativity. According to Lewis and Lovatt (2013), musical performance is an improvisation of creating something as 'new'. Within the frame of the transformation ability concept, it can be put forward that improvisation is a kind of the transformation from 'abstract' emotions to 'concrete' ones during playing an instrument in the music.

Non-routine problem solving process may be another alternative instrument to produce the new in regarding the visual arts area. The new sometimes may come from the artwork production in which is highly possible to encounter the non-routine problems frequently in the visual arts. These problems occur spontaneously during the artwork production process owing to the visual arts cannot be built on definite rules originating from its nature. According to numerous researchers, the non-routine problems can lead to explore the new as originality, because there is not a ready solution formula for solving process of these problems (Siegler, 1989; Urban, 1995). In this situation, we can expect that the solution process of the non-routine problem leads the students to discover the new through production of the artwork in the Visual Arts Education. 
The Role Of Art Education On The Creatıve Thınkıng Skılls Of Students In Musıc...

As regarding the music area, Hallam (e.g., 2010) stated this situation by referring to researchers' low road transfer that depends on automated skills as the processing of language whereas, 'high road transfer' requires reflection and conscious processing as adopting similar skills for solving of different problems in the music area. Also, Peterson and Madsen (2010) stated that music students make high-road transfer when trying to play a different musical instrument apart from the learned musical instrument in music teaching. According to them, such an initiative supports the creativity in the Music Education. Then, it can be put forward that this situation is a kind of problem as the nonroutine problem for music students that needed to be solved. At this point, Bújez and Mohedo-Díaz (2014) claimed that music can encourage students' creativity for exploring, discovering and originality. This situation can be explained by the non-routine problem solving process which leads the creative outcomes in the Visual Arts and Music Education disciplines especially regarding the Originality. Also, the improvisation as a performance of music teaching can be added in the process of producing the originality. Among the musicians, Kleinmintz et al. (2014) found that group with improvisation scored higher on the originality compared to the non-improvisation group on divergent thinking tasks. In contrast to that, some previous study findings reported that there existed some uncertainties about the impact of the Art Education upon the creative thinking of the students who were especially in the music education beyond producing the new as originality as follow.

Charyton, Basham, and Elliot (2008) found that there was no significant difference among the psychology, engineering, English, and music students regarding creativity skill. On the other hand, Furnham, Batey, Booth, Patel, and Lozinskaya (2011) found that there was a significant difference between the art students (mixed of both visual arts with music students) and science students regarding the creativity in favor of the art ones in university. In contrast, Howell (1990) reported that significant difference was not found regarding the creativity scores among the university students in the music, visual arts, dance, and theater education. In higher education level, some previous study findings indicated that many different results existed as related to the creative thinking by comparing art students with each other or non-art education disciplines' students. On the other hand, as Hamann, Bourassa, and Aderman (1991) stated, the studies of creativity in the literature related to the art area was limited by some art disciplines exclusively. Similarly, Hallam (2010) stated that the investigation about role of music in the creativity was paid less attention by researchers. In addition, Runco (2014) stated that just a few study investigated the creativity in the art education field. Also, as The College Board (2012) reported, the investigations at the high school level are less than the ones at the other education levels such as elementary education.

\subsection{The Purpose of the Study}

Accordingly, previous study findings in the literature indicate that further study should be conducted on this topic to reveal the role of the art education disciplines on the creative thinking for an understanding of creative thinking development. Therefore, this study aimed to determine the role of art education disciplines of Music Education or Visual Arts Education as central disciplines on the creative thinking skill comparing the students in these education disciplines. Thus, this study was unique by aiming to investigate the role of the visual arts and music education upon the creative thinking of the Turkish students including the Grades 9-12, especially regarding the Music Education. Therefore, 
present study includes two parts as the investigation of the art education disciplines' role upon the creative thinking skills of the students. The first part of the study was the comparison of the music and the visual arts Grade 12 students regarding creative thinking skills as causal-comparative research design. The second part of this study was also the comparison of music senior students (Grade 12) and junior (Grade 9) ones on creative thinking skills as cross-sectional research design. That is, Grade 12 music students also participated in both parts of this study as data set. Initially, it was compared the students (Grade 12) in both the visual arts and music sections to determine whether there is a potential source of differences of the students' creative thinking regarding the art education disciplines. For this first part of the study, it was determined the research question as followed:

Q1. Is there a significant difference between Grade 12 music students and visual arts students regarding the creative thinking and the originality skills?

As second part of the study, it was investigated on whether there is a potential source of differences among the Grade 9 and Grade 12 music students' creative thinking skills. Hence, this part of the study focused on whether there is significant difference between music students' creative thinking skills within music learning regarding the senior or junior students.

Q2. Is there a significant difference between Grade 12 students and Grade 9 students in the Music Education regarding the creative thinking and the originality skills?

\section{METHOD}

This study was designed as two parts to investigate the role of the art education disciplines as the Music Education and the Visual Arts Education upon the creative thinking skills of the art students. The first part was designed as causal-comparative design to investigate the role of the art education disciplines on whether there was a significant difference between the music students and the visual arts students' creative thinking and the originality skills. Accordingly, the Music Education Grade 12 music students were compared to the visual arts ones (Grade 12) with using of the art education discipline as an independent variable in the causal-comparative design.

The second part of this study was designed as cross-sectional to investigate the role of the Music Education on the creative thinking skills of the students. The comparison was made between the music students in Grade 9 and Grade 12 on whether there was a significant difference between junior and senior music students' creative thinking and the originality skills. Accordingly, both the Causal - Comparative and Cross - Sectional research designs were implemented in this study as using inferential statistics to reveal the role of art education disciplines in the creative thinking of the students.

\subsection{Analysis of Data}

This study was designed to determine whether any significant differences existed between creativity scores of the High School of Art students. Accordingly the study includes two parts as follows:

(a) Comparing Grade 12 music senior students with Grade 12 visual arts senior students.

(b) Comparing senior music students (Grade 12) with junior music students (Grade 9). 
The Role Of Art Educatıon On The Creatıve Thınkıng Skılls Of Students In Musıc...

Therefore, Analysis of Covariance (ANCOVA) was used to reduce the possible effects of external validity on the dependent variable. Accordingly, the age was assigned as a covariate in the ANCOVA due to it is an important variable in the development of creative thinking. As the pre-existing variable, the art education disciplines (music and visual arts education departments) were assigned for the independent variable. Thus, the measurement of creative thinking of students (TTCT) was also assigned as the dependent variable. In the second part of this study as the cross-sectional, it was also used the ANCOVA. Likewise, the age was assigned as a covariate. The measurement of creative thinking of students was the dependent variable. The junior students in Grade 9 and senior (Grade 12) students in the Music Education as the grades were designated for the independent variable in the analysis of covariance.

\subsection{Participants}

The students of the Muzaffer Sarısözen High School of Art participated in this study in 2014 autumn. 13 students ( 10 girls, 3 boys $M$ age $=17.15$ as Grade 12 ) and 17 students (Grade 9) in the department of Music Education participated the study. The eleven students $(M$ age $=14.6)$ in the Grade 9 were girls $(6$ boys, $M$ age $=15.16)$. In terms of the department of visual arts education, 22 students (14 girls, 8 boys $M$ age $=17.27$ ) participated as Grade 12. Wholly, 24 girls - 11 boys $(M$ age $=17.22)$ in Grade 12, and 11 girls -6 boys $(M$ age $=14.82)$ in Grade 9 . As a total, 52 high school art students who were in either visual arts or music education participated in this study. Students were following in the High School of Art located in an urban setting. Students were selected for study participation based on their degree of experience (senior and junior) in the visual arts and music education disciplines.

\subsection{Curriculum}

The Music Education in Grade 12, 56\% of total 34 lesson hours occurs of the music area as Musical Hearing \& Music Literacy, Piano, Turkish \& Western Musical Instruments, Turkish Choral Music, Western Choral Music, Turkish Musical Instruments Groups, Western Musical Instruments Groups, Individual Voice Learning and Music Styles. 24\% of total lesson hours consists of the theory lessons as Foreign Language, Turkish, Turkish Literature and Traditional Turkish Music History. The other lessons are related to lessons in specific areas as Traffic, Visual Arts, Physical Education, Religion \& Ethics Education and optional lessons. The Music Education students in Grade 9 have been taken 39 lesson hours in a week. $64 \%$ of total lesson hours consists of theory lessons as Math, Geometry, Physics, Chemistry, Biology, Geography, History, Turkish and Turkish Literature. 13\% of the total lesson hours consists of music area as 'Musical Hearing \& Music Literacy', 'Turkish \& Western Musical Instruments', 'Entrance of the Music and Piano'. The other lessons are related to lessons in various areas as Visual Arts, Physical Education, Religion \& Ethics Education, and optional lessons. The Visual Arts Education in Grade 12, 35\% of total 34 lesson hours is related to the visual arts field directly such as Artistic Drawing, Two-Dimensional Art Workshop and Graphic Design. 24\% of total 34 lesson hours is consistent of theory lessons of visual arts area as Art History, Turkish Art Painting \& Sculpture, Contemporary Art, and Art Criticism. 21\% of total lesson hours is including theory lessons as Foreign Language, Turkish and Turkish Literature. The other lessons are Physical Education, Music, Traffic, Religion \& Ethics Education and optional lessons (National Education Ministry [MEB], 2016a). 


\subsection{Measurement}

The data analyzed in this study was obtained from the Torrance Test of Creative Thinking (TTCT) Figural form which was designed by E. P. Torrance in 1966 to measure of creative thinking potential of children, adolescents and adults. The Figural Tests of TTCT contain Picture Construction, Incomplete Figures and Repeated Figures as activities (Torrance, 1966). In this study, it was used the 1984 scoring guide of TTCT in which is scored Fluency, Originality, Abstractness of (Titles), Elaboration, Resistance to Premature (Closure) and Creative (Strengths) as subscales.

TTCT was translated by Aslan (2001) into the Turkish language and performed on preschool, elementary, high school and university students $(N=922)$ to obtain the reliability and validity of this Turkish version of the TTCT. Accordingly, the Cronbach Alpha coefficient was found as .70 regarding the reliability. Also, the Wechsler Adult Intelligence Scale (WAIS) was compared with the Turkish version of the TTCT for the validity. Additionally, the original TTCT and the Turkish version of the TTCT were administered to participants who were fluent in Turkish and English languages in order to compare their scores for linguistic equivalence. Thus, it was reported by Aslan (e.g., 2001) that the analysis was provided at the end of all these studies for the reliability, validity and linguistic equivalence of Turkish version of TTCT.

\section{RESULTS}

The first part of this study as causal-comparative, it was not found a significant difference between Grade 12 music students and visual arts students $[F(1,32)=.17, p=.67]$ on the creative thinking (Table 1)

\section{Table 1.}

Analysis of Covariance for Creative Thinking and Creative Thinking Subscales Scores by the Groups as the Grade 12 Music Education Students and Grade 12 Visual Arts

Education Students

\begin{tabular}{lccc}
\hline TTCT and Subscales & MS & $\boldsymbol{F ( 1 , 3 2 )}$ & $\boldsymbol{\eta}^{\mathbf{2}}$ \\
\hline TTCT & 1.73 & .17 & .005 \\
Fluency & 15.26 & 1.22 & .037 \\
Originality & 70.29 & $5.92^{*}$ & .156 \\
Elaboration & 17.46 & 3.32 & .094 \\
Resistance of Premature (Closure) & 26.32 & $11.05^{* *}$ & .257 \\
Abstractness of (Titles) & 2.91 & .56 & .017 \\
Creative (Strengths) & 1.95 & .47 & .015 \\
\hline
\end{tabular}

${ }^{*} p<.05,{ }^{* * *} p<.01$

The senior music students' adjusted mean of creative thinking was $9.10(M$ unadjusted $=$ 9.29). However, the adjusted mean of senior visual arts ones was $9.57\left(M_{\text {unadjusted }}=9.46\right)$. Although, the visual arts students had a high mean score of the creative thinking than the music ones, this situation did not consist of significant difference between the music and visual arts senior students on the creative thinking skills (Table 2). 
The Role Of Art Education On The Creatıve Thınkıng Skılls Of Students In Musıc...

\section{Table 2.}

The Analysis of Covariance for the Grade 12 Music and Visual Arts Education students by the Unadjusted Mean and Adjusted Mean Scores of the TTCT and TTCT's Subscales

\begin{tabular}{lllccc}
\hline TTCT and Subscales & & Music Education $^{\mathbf{a}}$ & Visual Arts Education $^{\mathbf{b}}$ \\
\hline TTCT & & & & & \\
$\quad$ Unadjusted & $M(S D)$ & 9.29 & 2.67 & 9.46 & 3.56 \\
$\quad$ Adjusted & $M(S E)$ & 9.10 & .87 & 9.57 & .67 \\
$\begin{array}{l}\text { Fluency } \\
\quad \text { Unadjusted }\end{array}$ & $M(S D)$ & 13.38 & 3.92 & 11.72 & 3.43 \\
$\quad \begin{array}{l}\text { Adjusted } \\
\text { Originality }\end{array}$ & $M(S E)$ & 13.21 & .98 & 11.83 & .75 \\
$\quad$ Unadjusted & $M(S D)$ & 7.53 & 4.80 & 4.18 & 2.83 \\
$\quad$ Adjusted & $M(S E)$ & 7.29 & .96 & 4.32 & .73 \\
Elaboration & & & & & \\
$\quad$ Unadjusted & $M(S D)$ & 9.69 & 2.13 & 11.09 & 2.34 \\
$\quad$ Adjusted & $M(S E)$ & 9.64 & .63 & 11.12 & .49 \\
Closure & & & & & \\
$\quad$ Unadjusted & $M(S D)$ & 1.69 & .85 & 3.40 & 1.84 \\
$\quad$ Adjusted & $M(S E)$ & 1.63 & .43 & 3.44 & .33 \\
Titles & & & & & \\
$\quad$ Unadjusted & $M(S D)$ & 2.23 & 2.04 & 2.77 & 2.36 \\
$\quad$ Adjusted & $M(S E)$ & 2.19 & .63 & 2.79 & .48 \\
Strengths & & & & & \\
$\quad$ Unadjusted & $M(S D)$ & 2.38 & 1.44 & 2.77 & 2.30 \\
$\quad$ Adjusted & $M(S E)$ & 2.31 & .56 & 2.81 & .43 \\
\hline${ }^{a} N{ }^{b} N=22$ & & & & &
\end{tabular}

${ }^{a} N=13,{ }^{b} N=22$

Table 3.

Analysis of Covariance for Creative Thinking and Creative Thinking Subscales Scores of the Grade 9 and Grade 12 Music Education Students

\begin{tabular}{lccc}
\hline TTCT and Subscale & MS & $\boldsymbol{F ( 1 , 2 7 )}$ & $\boldsymbol{\eta}^{\mathbf{2}}$ \\
\hline TTCT & 18.37 & 2.89 & 0.97 \\
Fluency & 1.91 & .14 & .005 \\
Originality & 55.86 & $4.35^{*}$ & .139 \\
Elaboration & .67 & .16 & .006 \\
Resistance of Premature (Closure) & .20 & .32 & .012 \\
Abstractness of (Titles) & 2.04 & .54 & .020 \\
Creative (Strengths) & 13.01 & $6.48^{*}$ & .194 \\
\hline
\end{tabular}

${ }^{*} p<.05$

For the subscales, ANCOVA detected the significant difference between the senior music and visual arts students $\left[F(1,32)=5.92, p<.05, \eta^{2}=.156\right]$ on the originality in favor of music ones. In contrast to that, there was a significant difference between the senior music and visual arts students $\left[F(1,32)=11.05, p<.01, \eta^{2}=.257\right]$ on the closure in favor of visual arts ones as seen in Table 1 and Table 2 . 
As the cross-sectional part of this study, the ANCOVA analysis revealed that there was no significant difference between the students of Grade 9 (junior) and Grade 12 (senior) in the Music Education $[F(1,27)=2.89, p=.10]$ regarding the creative thinking (Table $3)$.

The adjusted mean of the senior students and junior ones were $10.78\left(M_{\text {unadjusted }}=9.29\right)$ and 7.27 $\left(M_{\text {unadjusted }}=8.42\right)$ respectively, as seen in Table 4. Although the senior students' adjusted mean is higher than junior students, it does not occur a significant difference between them in terms of creative thinking skills. On the other hand, ANCOVA revealed the significant difference on the Originality $[F(1,27)=4.35, p<.05]$ between the senior and junior music students. The other significant difference among music students was on the Strengths $[F(1,27)=6.48, p<.05]$ as subscale of creative thinking (Table 3$)$. The senior music students had a mean score on the 'originality' $\left(M_{\text {adjusted }}=9.83\right)$ and the 'strengths' ( $\left.M_{\text {adjusted }}=3.80\right)$ higher than the junior students' ones (Originality; $M_{\text {adjusted }}$ $=3.71$ - Strengths; $M_{\text {adjusted }}=.85$ ) seen in Table 4 .

\section{Table 4.}

The Analysis of Covariance for the Grade 9 and Grade 12 Music Education Students by the Unadjusted Mean and Adjusted Mean Scores of the TTCT and TTCT's Subscales

\begin{tabular}{|c|c|c|c|c|c|}
\hline \multirow{3}{*}{$\begin{array}{l}\text { TTCT and Subscales } \\
\text { TTCT }\end{array}$} & & \multicolumn{4}{|c|}{ Music Education } \\
\hline & & \multicolumn{2}{|c|}{ Grade $9^{a}$} & \multicolumn{2}{|c|}{ Grade $12^{b}$} \\
\hline & & & & & \\
\hline Unadjusted & $M(S D)$ & 8.42 & 2.48 & 9.29 & 2.67 \\
\hline Adjusted & $M(S E)$ & 7.27 & 1.00 & 10.78 & 1.25 \\
\hline \multicolumn{6}{|l|}{ Fluency } \\
\hline Unadjusted & $M(S D)$ & 14.41 & 3.27 & 13.38 & 3.92 \\
\hline Adjusted & $M(S E)$ & 14.45 & 1.45 & 13.32 & 1.81 \\
\hline \multicolumn{6}{|l|}{ Originality } \\
\hline Unadjusted & $M(S D)$ & 5.47 & 2.50 & 7.53 & 4.80 \\
\hline Adjusted & $M(S E)$ & 3.71 & 1.43 & 9.83 & 1.78 \\
\hline \multicolumn{6}{|l|}{ Elaboration } \\
\hline Unadjusted & $M(S D)$ & 9.58 & 1.90 & 9.69 & 2.13 \\
\hline Adjusted & $M(S E)$ & 9.92 & .81 & 9.25 & 1.01 \\
\hline \multicolumn{6}{|l|}{ Closure } \\
\hline Unadjusted & $M(S D)$ & 1.00 & .79 & 1.69 & .85 \\
\hline Adjusted & $M(S E)$ & 1.45 & .31 & 1.09 & .39 \\
\hline \multicolumn{6}{|l|}{ Titles } \\
\hline Unadjusted & $M(S D)$ & 1.94 & 1.85 & 2.23 & 2.04 \\
\hline Adjusted & $M(S E)$ & 2.57 & .77 & 1.40 & .96 \\
\hline \multicolumn{6}{|l|}{ Strengths } \\
\hline Unadjusted & $M(S D)$ & 1.94 & 1.59 & 2.38 & 1.44 \\
\hline Adjusted & $M(S E)$ & .85 & .56 & 3.80 & .70 \\
\hline
\end{tabular}

As a result, the significant differences in creative thinking subscales as originality and strengths were in favor of senior music students (Grade 12). The effect size $\left(\eta^{2}\right)$ of the Music Education on the originality and the strengths were computed as 0.139 and 0.194 (Table 3) respectively. 
The Role Of Art Educatıon On The Creatıve Thınkıng Skılls Of Students In Musıc...

\section{DISCUSSION}

The first research question of this study was on whether there was significant difference between senior music and visual arts students (Grade 12) regarding the creative thinking and the originality skills. As a result, it was no found a significant difference between the senior music and visual arts students' creative thinking skills. This result is supported by Hamann and scholars (1991), who compared the music students with the visual arts ones in high school level (Grades 7 and 12). The present result is also supported by Newton and Beaverton (2012); the creativity was found as equal between the visual arts (as drawing and painting) students and music students.

In this manner, Lapidaki (2014) stated that education can give opportunities to music and visual arts students to learn awareness of the creativity by maintaining themselves in a constant condition. It can be speculated that situation was mentioned by researchers in the field of the art education. For instance, Hickey and Webster (e.g., 2001) stated that the ability of creativity of students can be revealed in music learning. Similarly, Randles and Smith (2012) stated that music education in both U.S. and English promote the students to create music as composition and improvisation within the school music curriculum. Perhaps, therefore, Campbell (e.g., 1990) emphasized that the creative thinking is demonstrated through the music all over the world. Regarding visual arts, Miga et al., (2000) stated that there was a significant causal relation between visual arts study and the creativity. Accordingly, based on current result, it can be put forward that music and the visual arts as art education disciplines do not possess a privilege level on creative thinking development of students. In other words, the music students and visual arts students can be similar regarding the creative thinking acquirement. Thus, it can be speculated that Music Education and the Visual Arts Education may be having similar role in the creative thinking development of the art students. This result indicates that creative thinking skill as education gain of the Music Education and the Visual Arts Education disciplines can also be synonymous.

Doubtless, there can be many reasons for this result as related to the art education disciplines. For example, art making as an exploration of experience is in the range of the learning and creativity (Carabine, 2013). Regarding the Visual Arts Education, as Pavlou (2013) stated, a making of the artwork within the visual arts lessons exhibits the creativity in a way of the visual. Therefore, the art education can play the most important role in our visual world to help students with using their creative skills (e.g., Zimmerman, 2009). As Zimmerman (2009) stated, the people can be creative in particular domains as visual arts. Consequently, Van de Kamp, Admiraal, Van Drie and Rijlaarsdam (2015) claimed that one of the major goals of the Visual Arts Education is to development of the students' creativity. Thus, it can be put forward an idea that art-making activities in the Visual Arts Education support the students' creative thinking. This situation may be explained by the words of the statement that is belonged to John Dewey. According to him, the visual activity can improve the individual's creative skill when he/she transforms the visual thing into an art form.

On the other hand, it may also be shown the non-routine problem solving process as the other reason of present result regarding the synonymous of the creativity for the Music Education and the Visual Arts Education. Due to the visual arts cannot be built on distinct rules, it can be speculated that non routine problems are frequently encountered in the visual arts area during the artwork production. That is, the structure of visual arts area 
can tend to produce the new problems as non-routine ones. Hence, it is highly possible that frequency of encountering non-routine problems can be existed in visual arts area more than other specific areas. This situation can also be available for the music area. Especially, regarding the solving process, this type problems can be creative impacts during the music production. For example, DeLorenzo (1989) found that highly problem solvers explored sounds for musical expressiveness as helping to higher levels of musical thinking. In contrast to that, poorly problem solvers' decision making was based on their musical anxieties. It is emphasized that these problems support the divergent thinking in terms of solving process (e.g., Runco, 2014). Because, the ability to see the problems of the students can affect the problem-solving process (DeLorenzo, 1989).

The divergent thinking is an expression of the creative thinking, and it is known that is necessary for the creative thinking. Because, the divergent thinking shows itself as positive in creative thinking achievement (Cropley, 2001). Also, the non-routine problem solving process promotes the divergent thinking which can lead creative thinking (e.g., Runco, 2014), since the students can be more motivated when they choose their own problem solving tasks themselves (Fasko, 2001). Then, it can be expected that nonroutine problem solving process can support the creative thinking development. Accordingly, it can be speculated that art-making activities involving the non-routine problem solving process contribute to the creative thinking development of the music and visual arts students significantly.

However, Hickey (2001) also stated that there are some major causes between past and present in the music learning more assertive than ever before regarding creative thinking. For instance, the developing information currently is helpful for teachers to attract their students in today regarding creative musical activities. Likewise, our understanding on the learning of the creative thinking has expanded greatly in the last decades. Additionally, improvements in music education technology have provided great assistance to students in terms of enhancing of creative music education. This situation is supported by Nielsen (2013), who found that music technology course provided such an environment for students to be creative. Similarly, Kokotsaki and Newton (2015) referring to researchers emphasized that there is an influencing factor of information and communication technology through enhancing the children's creative musical activity in the music learning. Under the present result, it can be put forward that the Music Education and the Visual Arts Education have some specific opportunities within their educational disciplines, but these art education disciplines can possess a synonymous role in the creative thinking development of the students as educational gain.

Conversely, the originality subscale of creative thinking, as another aspect of the first research question, was found a significant difference in favor of the senior music students (Grade 12). In contrast, the Grade 12 visual arts students had closure scores higher than the music ones (Table 1, Table 2). In another saying, the Originality skill of music students in Grade 12 was higher significantly when compared with the visual arts students (Grade 12). It can be said that current result is consistent with the previous study of Kleinmintz et al. (2014).

The 'originality' is related to the unique ideas visualized regarding the measure of creative thinking in the TTCT. This situation is understandable thing for the visual arts students in aspect of drawing inclination, whereas it may not exist in similar inclination for the music students. Kokotsaki (2012) emphasized that the development of knowledge 
The Role Of Art Educatıon On The Creatıve Thınkıng Skılls Of Students In Musıc...

and instrumental skill facilitate to use musical imagination. Accordingly, it can be said that unique ideas as art-making may be produced by playing a music instrument to use musical imagination for the music area. To go out of this known route is possible by means of spontion approach. Inevitably, this spontion as the process can be reflected easily by playing a music instrument. As Hallam (2010) stated, the development of creative skills is likely to be particularly dependent on the type of musical engagement. Hamann et al. (1991) reported that improvisation techniques tended to be associated with subjects' creativity scores. Additionally, Hallam (2010) concluded that the improvisation activities in music significantly support the development of creative thinking as opposed to the didactic teaching in the development of children and young people. Hence, as based on researchers, Kokotsaki and Newton (2015) stated that musical creativity can be exhibited with composition and improvisation. According to prominent researchers composition and improvisation are considered as the main activities for generating new ideas in music as additional forms of creative behavior (Kokotsaki, 2012). This situation is also supported by recent study by Koutsoupidou and Hargreaves (2009), who found that improvisation and composition in music education improve students' musical originality in a comparison study of 6-year-olds in terms of an intervention improvisation program with didactic music lessons. Also, Coulson and Burke (2013) found that students aged between 5-11 years in music classrooms produce more creative and original music after improvisation lessons. Considering the National Education Ministry [MEB] (2016b) curriculum, one of the possible reasons of the present result regarding the originality skill of Grade 12 music students with high scores can be related to more practice activities (weekly 17 hours) in their application lessons when compared to the Grade 12 visual arts students (weekly 12 hours). In other words, Visual arts students (Grade 12) had less visual arts lessons in practice when compared to music students in Grade 12 in terms of related to their own art areas. Cropley (2001) as based on researchers stated that production of novelty includes making a large number of relationships randomly and creativity is accepted as novel transformations. Gestalt psychology explained that novelty is produced by the new experience unexpectedly (Cropley, 2001). To this point, it can be said that transformation leads the novelty including the new experiences randomly in music area which is called as improvisation. The originality may take the form such as the novelty (Runco, 2014). Thus, the originality can play an important role in this transformation.

On the other hand, the novel transformations in visual arts area can be realized by transformation from visual images to pictorial ones predominantly in application activities. Runco (2014) stated that transformation regarding personal creativity constructs original interpretations of experience. In this point, perhaps, a decrease of originality interpretations of Grade 12 students in the visual arts education occurred by the decreasing application lesson hours in the curriculum. Although there was no significant difference between Grade 12 music and Grade 12 visual arts students in terms of total creativity scores, it was meaningful that music Grade 12 students had higher originality scores significantly than Grade 12 visual arts students. This result may be clarified by another result of this study obtained from comparing of Grade 12 music students with Grade 9 music students as follows: While Grade 9 music students had four hours application lessons in a week, Grade 12 students had 17 hours application lessons weekly (MEB, 2016b). This result is meaningful for the increasing of the originality scores of the students as parallel of the increasing of the practice lessons. That is, the novel productions, as originality, might be encouraged and increased by the improvise music as regard to the Grade 12 music students. In this situation, it is possible that of the 
originality depends on applications more than theory lessons in the Music Education. To this point, Bújez and Mohedo-Díaz (2014) stated that music might encourage the originality of students' creativity, because the improvisation refers to the act of creating new music (Kokotsaki, 2011). As Hargreaves (2012) stated, musical creativity is seen in the activities of composition, improvisation and performance which can lead to a more fundamental view of imagination. Based on Singer's definition in 1999, the images are production that is obtained from basic senses originally (Runco, 2014). Already, imagination is the new due to it is consisted of the images in a novel product during the cognitive process, it can be said that improvisation is sensed as the originality in the concept of the musical creativity. Considering that improvisation is the process of producing new ideas in music without any restriction or editing (Koutsoupidou \& Hargreaves, 2009), one may see the originality in musical creativity as a common component as the improvisation. Accordingly, it is possible to say that the improvisation in the music education supports the originality skills of the students in Grade 12 more than in Grade 9. In other words, the sustaining of the Music education can be an important factor to the development of the originality skills of the students through the application lessons as making practice.

The other result of the present study regarding creative thinking subscale was related to the Closure. The Grade 12 visual arts students' closure scores were significantly higher than the Grade 12 music students. The closure is concerning with probing, which demands open-minded (Kim, 2011). Thus, recognizing the problem is possible through remaining open-minded. Furnham, Trew, and Sneade (1999) found that musical stimulation had an insignificant effect on a manual task. However, it is known that the visual arts students frequently engage manual tasks as a kind of problem for the students as the non-routine problem. Also, it is known that students can be more motivated when they select their own problem solving way (e.g. Fasko, 2001). Hence, this positive motivation can be acted by the non-routine problem solving process for the visual arts students. According to present result, it is possible that such as problem solving tasks include more motivation for the visual arts students than music students. Thus, the closure may be developed by non-routine problem solving process in the visual arts learning.

On the other hand, Kim (2006) found that innovative factor of creative thinking is loaded by the Fluency, Originality and Closure subscales. Also, Cho, Nijenhuis, Annelies, Kim, and Lee (2010) found that 'closure' is correlated with intelligence rather than the 'originality'. Based on the previous study findings, it can be put forward that originality represents innovative factor more than closure. This situation can be explained by the closure approach that may be more pragmatic than the originality regarding the cognitive process. That is, the significant difference regarding the Closure subscale among the art students in the present study could be originated from the problem solving approach of the music and visual arts students. Hence, the visual art students (Grade 12) may also be have a more pragmatic aspect of the creative thinking than Grade 12 music students. Considering pragmatists tend more to contemplate the problem regarding the solving process including both convergent and divergent thinking, it can be expected that visual arts students may possess pragmatic approach to the problems in the creative thinking process. In contrast to that, music students may tend more innovative approach to the problems with regard to solving process due to music engages more idealist practices spontaneously such as improvisation. Accordingly, music students may possess an 
The Role Of Art Education On The Creatıve Thınkıng Skılls Of Students In Musıc...

idealist approach in the creative thinking process. Therefore, the musical creativity is largely seen as being demonstrated itself in the activities of performance with improvisation (e.g., Hargreaves, 2012; Hickey \& Webster 2001).

According to present result, it can be speculated that the Music Education improves the innovative aspect of idealism in cognitive process of the creative thinking for the music students in the sense of the originality. Whereas, it can be claimed, the Visual Arts Education as well develops the innovative aspect of pragmatism of the creative thinking of students in the way of the closure. In this manner, it can be said that the art education disciplines as the Music Education and the Visual Arts Education possess dissimilar advantages and roles on the creativity of the students in specific aspects of the creative thinking.

The second research question of the present study was on whether the significant difference between senior and junior music students regarding the creative thinking and originality subscale. When compared Grade 9 music students with Grade 12 music ones, it was not found a significant difference among the students regarding the creative thinking skills. The present result is consistent with the view of Hickey and Webster (e.g., 2001), who concluded that every child has the potential for creative development and it can be revealed within music activity or by giving music tasks. However, it was found a significant difference between senior and junior music students' Originality and the creative (Strengths) subscales in favor of senior (Grade 12) music students. Hargreaves (2012) stated that musical creativity can lead to the imagination as the cognitive basis of musical activity. According to Runco (2014) the images reproduce products as the original. Accordingly, the present result is also supported in the sense of the creativity of music improvisation by Kiehn (2003). He compared the Grade 2, Grade 4 and Grade 6 students. In that study, Kiehn found that Grade 6 students scored higher significantly than initial classroom students regarding improvisation. Also, Hallam (2010) stated that some changes may occur with the use of different musical activities over long periods of time in the brain which influences our developed skills through transferring to other activities. The meaning of this, the music student may be engaging and exploring many aspects of the music activities when pursuing the music education in a long period of time. Considering the present result, it can be speculated that is important to pursue the music education for the development of students' originality skills through the improvisation. These clarifications can give us an opportunity with present result that creativity in the music area can occur during musical activity originally. Then, it may be predicted that student's musical activity in music education increases gradually regarding the originality skill from Grade 9 toward Grade 12. This progressive trend as producing of the imagination originally can also be supported by made more practice of doing musical activities in the lessons of the Music Education. Due to the improvisation in the music activity leads to imagination (e.g. Hargreaves, 2012), children's own musical imagination may contribute to children's development in terms of the originality (Hogenes, Diekstra, \& Sklad, 2016). At this point, it is possible that music students in the musical activity (more or less) may tend to improvise. As Rutkowski (1994) stated, during the adolescent age youths engage in music composition and it has been observed that many students engage in out-of-school music activities opposite to traditional school performing. Hence, music students, as an adolescent in high school level, would be bored with adhering to play the music notes when they entered a certain quest. In this situation, images originally can be reproduced as imagination during improvisation music and this process may show 
itself as originality in musical activity. Because; the improvisation supports the originality of the music (e.g. Coulson \& Burke, 2013; Kokotsaki, 2011; Koutsoupidou \& Hargreaves, 2009).

The other aspect of the present result that senior music students had high scores significantly than junior music students (Grades 12-9) in the Strengths as the other subscale of creative thinking. Since Torrance (e.g., 1966) stated that the creativity was sensitive to the problems, gaps, missing elements and deficiencies. In this way, the (creative) strengths can be assessed that they are to be sensitive on the irregular thing, because of the irregular things may be perceived as a problem. Thus, individual can improve her/his creativity through transforming the irregular things to regular ones (solving the problem). Peterson and Madsen (2010) reported that teaching of creative thinking through music activities is possible in the secondary music classrooms as transfer of information. According to them, if a student picks up a bowed instrument after having learned to play the guitar, this student may spend effort to find similarities between the two instruments (High-road transfer) in conscious process. Peterson and Madsen (e.g., 2010) stated that the Music Education supplies many experiences such as instrument practices. They also added that the ability of information transfer from one situation to another encourage the creativity.

Accordingly, the musical performance may be the most important component through transferring some information to another in terms of supporting the creativity. That is, the manual tasks in music education may increase the creative strengths positively through these practical inferences from irregularities to regularity ones. It can be seen that present result is consistent with outcomes of the lesson of Keeping and Repairing of the Musical Instrument which has just only been given to students in Grade 12. This lesson is based on manual tasks that is only taken place in the Music Education curriculum of the Grade 12 (MEB, 2016b).

To this study, intact groups participated such as Grade 12, Grade 9 of the Music Education and Grade 12 of the Visual Arts Education. Although this limitation, the present study was the first to study the role of the art education disciplines as the Music Education and the Visual Arts Education including Turkish students in terms of the variety of the samples. On the other hand, the initial implication of the study was to reveal the role of the Music Education upon the students' originality skills. The other implication was that the music students might tend to possess an ideal style of creative thinking. In contrast to that, the visual arts students may as well, tend to possess a pragmatic style of creative thinking. As another implication on the (creative) strengths skills of the music students was that Grade 12 music students might be developed the creative strengths skills more in comparison of Grade 9 music students by doing practice manually with music instruments.

\section{CONCLUSIONS}

Hogenes, Diekstra, and Sklad (2016) reviewed the literature and they reported that educational researches on music education could be divided into three parts as academic performance, cognitive task performance and cognitive processes. In this manner, the present study' results can be assessed in the aspect of cognitive processes as creative thinking. As a consequence of this study, it can be said that the creative thinking is synonymous as education outcomes in both terms of the Music Education and the Visual 
The Role Of Art Education On The Creatıve Thınkıng Skılls Of Students In Musıc...

Arts Education. However, this result was not similar in the creative thinking subscales in terms of the Closure, Originality and the Strengths as the specific aspect of the creative thinking. As main education outcome, the present result indicates that the originality can be a significant gain of the Music Education. Based on the present study's result, it can be concluded that the Music Education and the Visual Arts Education have different advantages in the development of the creative thinking skills of students. For instance, the improvisation may be an important factor in the development of the originality skills of the students in the Music Education. In contrast, the non-routine problem solving process in which may be occurred in artwork production can be vital for the improvement of the Closure skills of the students in the Visual Arts Education. Therefore, it can be concluded that visual arts students tend to have a pragmatist approach in the creative thinking process. In contrast, the music students may engage more idealist practices in the creative thinking process. Also, it can be concluded that the Music Education may encourage the creative Strengths of students during manual tasks for students to transfer the information through playing or repairing different music instruments in terms of practicing. Consequently, this study was put into practice at the high school level. Therefore, it is firmly suggested that further study should be conducted at various education levels. In addition, it can be also suggested that further study should be conducted to compare jazz music students with classical music students to determine the role of the improvisation on the originality skills of the students in the Music Education. 


\section{REFERENCES}

Aslan, A. E. (2001) Torrance yaratıcı düşünme testinin Türkçe versiyonu. [Turkish version of Torrance's tests of creative thinking]. Marmara Üniversitesi Atatürk Ĕ̌itim Fakültesi Ĕ̌itim Bilimler Dergisi, 14, 19 - 40.

Bújez, A. V. \& M.T. Mohedo- Díaz. (2014) Creativity in the music classroom. Procedia - Social and Behavioral Sciences 141, 237 - 241.

Campbell, P. S. (1990). Cross cultural perspectives of musical creativity. Music Educators Journal, 76, 43 - 46.

Carabine, J. (2013) Creativity, art and learning: A psycho-social exploration of uncertainty. IJADE, 32, 33 - 43.

Charyton, C., Basham, K. M. \& Elliot, J. O. (2008). Examining gender with general creativity and preferences for creative persons in college students within the sciences and the arts. Journal of Creative Behavior, 42, 149 - 222, doi: 10.1002/j.2162-6057.2008.tb01296.x

Coulson, A. N. \& Burke, B. M. (2013). Creativity in the elementary music classroom: A study of students' perceptions. International Journal of Music Education, 31, 428 - 441, doi: 10.1177/0255761413495760

Cho, S. H., Nijenhuis, J. T., van Viannen, A. E. M., Kim, H-B., \& Lee, K. H. (2010) The relationship between diverse components of intelligence and creativity. The Journal of Creative Behavior, 44, 125 - 137, doi: 10.1002/j.21626057.2010.tb01329.x

Cropley, A. (2001) Creativity. London: Kogan Page.

DeLorenzo, L. C. (1989). A field study of sixth-grade students' creative music problemsolving processes. Journal of Research in Music Education, 37(3). 188-200. doi: $\quad 10.2307 / 3344669 . \quad$ Retrieved from http://jrm.sagepub.com/content/37/3/188.abstract

Fasko, D. (2001). Education and creativity. Creativity Research Journal, 13, 317 - 327, doi: 10.1207/S15326934CRJ1334_09

Furnham, Batey, Booth, Patel, and Lozinskaya (2011). Individual difference predictors of creativity in art and science students. Thinking Skills and Creativity, 6, 114 - 121, doi:10.1016/j.tsc.2011.01.006

Furnham, A, Trew, S. \& Sneade, I. (1999) The distracting effects of vocal and instrumental music on the cognitive test performance of introverts and extraverts. Personality and Individual Differences, 27, 381 - 392.

Gombrich, E. H. (1991). Topics of our time: Twentieth-century issues in learning and in art. London: Phaidon.

Hallam, S. (2010). The power of music: Its impact on the intellectual, social and personal development of children and young people. International Journal of Music Education. 28(3) 269-289, doi: 10.1177/0255761410370658 
The Role Of Art Education On The Creatıve Thınkıng Skılls Of Students In Musıc...

Hamann, D. L., Bourassa, R. \& Aderman, M. (1991). Arts experiences and creativity scores of high school students, Contributıons to Music Educatıon, 18, 36-47. Retrieved from https://www.jstor.org/stable/pdf/24127318.pdf

Hargreaves, D. J. (2012) Musical imagination: Perception and production, beauty and creativity. Psychology of Music September 40: 539 - 557, doi: 10.1177/0305735612444893

Hickey, M. (2001). Creativity in the music classroom. Music Educators Journal, 88, 17 - 18, doi: 10.2307/3399771 Database: Academic Search Complete

Hickey, M. \& Webster, P. (2001) Creative thinking in music. Music Educators Journal, 88, 19 - 23 Published by: on behalf of Sage Publications, Inc. MENC: The National Association for Music Education Stable Retrieved from http://www.jstor.org/stable/3399772

Hogenes, M., Oers, B., Diekstra, R. F.W. \& Sklad, M. (2016). The effects of music composition as a classroom activity on engagement in music education and academic and music achievement: A quasi experimental study. International Journal of Music Education, 34(1), 32-48, doi: 10.1177/0255761415584296

Howell, C. D. (1990). The relationship between arts education and creativity among high school students. Unpublished doctoral dissertation, University of Northern Colorado. Retrieved from http://media.proquest.com/

Kerr, B. \& McKay, R. (2013) Searching for tomorrow's innovators: Profiling creative adolescents. Creativity Research Journal, 25, 21-32, doi:10.1080/10400419.2013.752180

Kiehn, M. T. (2003). Development of music creativity among elementary school students. Journal of Research in Music Education, 51, 278 - 288.

Kim, K. H. (2011). The creativity crisis: The decrease in creative thinking scores on the Torrance Test of Creative Thinking. Creativity Research Journal, 23, 285295, doi: 10.1080/10400419.2011.627805

Kim, K. H. (2006) Is creativity unidimensional or multidimensional? Analyses of the Torrance tests of creative thinking. Creativity Research Journal, 18, 251 - 259, doi: $10.1207 / \mathrm{s} 15326934$ crj1803_2

Kleinmintz O.M., Goldstein P., Mayseless N., Abecasis D., \& Shamay-Tsoory S.G. (2014). Expertise in musical improvisation and creativity: The mediation of idea evaluation. PLoS ONE 9(7): e101568. doi:10.1371/journal.pone.0101568 Retrieved from http://www.ncbi.nlm.nih.gov/pmc/articles/PMC4092035/

Kokotsaki, D. (2012). Pre-service student-teachers' conceptions of creativity in the primary music classroom. Research Studies in Music Education 34(2), 129156. doi: $10.1177 / 1321103 \mathrm{X} 12466770$

Kokotsaki, D. \& Newton, D. P. (2015) Recognizing creativity in the music classroom. International Journal of Music Education, 33(4), 491-508, doi: $10.1177 / 0255761415607081$ 
Kokotsaki, D. (2011). Student teachers' conceptions of creativity in the secondary music Classroom. Thinking Skills and Creativity 6, $100-113$, doi:10.1016/j.tsc.2011.04.001

Koutsoupidou, T. \& Hargreaves, D. J. (2009). An experimental study of the effects of improvisation on the development of children's creative thinking in music. Psychology of Music, 37, 251 - 278.

Kozbelt, A. (2004). Originality and technical skill as components of artistic quality. Emprical Study of the Arts, 22, 157 - 170, doi: 10.2190/NDR5-G09N-X7RE$34 \mathrm{H} 7$

Lapidaki, E. (2014) Artistic reciprocity as course-based practice of crossing 'monoartistic' boundaries in higher visual arts and music education. Journal of Visual Art Practice,13, 150 - 157, doi:10.1080/14702029.2014.959723

Lewis, C. \& Lovatt, P. J. (2013). Breaking away from set patterns of thinking: Improvisation and divergent thinking. Thinking Skills and Creativity 9, 4658, doi: 10.1016/j.tsc.2013.03.001

MEB; National Education Ministry (2016a) Retrieved from http://ttkb.meb.gov.tr/program2.aspx

MEB; National Education Ministry (2016b) Retrieved from https://ogm.meb.gov.tr/meb_iys_dosyalar/2012_09/05092630_ogmhd201220 13.pdf

Miga, E., Burger, K., Hetland, L., \& Winner, E. (2000). Does studying the arts engender creative thinking? Evidence for near but not far transfer. Journal of Aesthetic Education, 34, 91 - 104.

Newton, L. \& Beverton, S. (2012). Pre-service teachers' conceptions of creativity in elementary school English. Thinking Skills and Creativity, 7, 165 - 176, doi:10.1016/j.tsc.2012.02.002

Nielsen, L. D. (2013). Developing musical creativity: Student and teacher perceptions of a high school music technology curriculum Updqte, 31(2) 54-62. doi: $10.1177 / 8755123312473610$.

Pavlou, V. (2013) Investigating interrelations in visual arts education: Aesthetic enquiry, possibility thinking and creativity. International Journal of Education through Art. 9, 71 - 88, doi: 10.1386/eta.9.1.71_1

Peterson, C. W. \& Madsen, C. K. (2010). Encouraging cognitive connections and creativity in the music classroom. Music Educators Journal. 97, 25 - 29, doi:10.1177/0027432110386613

Randles, C. \& Smith, G. D. (2012). A first comparison of pre-service music teachers' identities as creative musicians in the United States and England. Research Studies in Music Education 34(2), 173-187. doi: 10.1177/1321103X12464836

Rostan, S. M. (2005). Educational intervention and the development of young art students' talent and creativity. Journal of Creative Behavior, 39, 237 - 261, doi: 10.1002/j.2162-6057.2005.tb01260.x 
The Role Of Art Education On The Creatıve Thınkıng Skılls Of Students In Musıc...

Runco, M. A. (2014) Creativity. (Second Edition). U.S.A.: Elsevier Inc.

Rutkowski, J. (1994).A Comparison of adolescents' in-school and out-of-school music experiences and involvement. Applications of Research in Music Education, 13(1), 17-22. doi: 10.1177/875512339401300104 Retrieved from http://upd.sagepub.com/content/13/1/17.extract

Siegler, R. S. (1989). How domain-general and domain-specific knowledge interact to produce strategy choices. Merrill-Palmer Quarterly, 35, 1-26.

The College Board (2012). Child development and arts education: A review of recent research and best practices, New York, N.Y., January 2012. Retrieved from http://www.advocacy.collegeboard.org/preparation-access/arts-core

Torrance, E. P. (1966) Torrance Tests of Creative Thinking. Princeton, New Jersey: Personnel Press, Inc.

Urban, K. K. (1995) Openness: A “magic formula" for an adequate development and promotion of giftedness and talents?! Gifted and Talented International, 10, $15-19$.

Van de Kamp, M.-T., Admiraal, W., Van Drie, J. \& Rijlaarsdam, G. (2015) Enhancing divergent thinking in visual arts education: Effects of explicit instruction of meta-cognition. British Journal of Educational Psychology, 85, 47 - 58, doi: 10.1111/bjep.12061

Zimmerman, E. (2009) Reconceptualizing the role of creativity in art education theory and practice. Studies in Art Education A Journal of Issues and Research, 50, $382-399$. 


\section{GENIŞLETILMIŞ ÖZET}

\section{Giriş}

Oldukça yaygın bir görüşe göre, sanat yaratıcı bir alan olarak öğrencilerin yaratıcı düşünmelerini geliştirmektedir. Alan uzmanı pek çok araştırmacı tarafından da bu görüş paylaşılmaktadır. Buna karşın, sanatın bütüncül yapı itibariyle mi yoksa disiplinler adına mı yaratıcı düşünme üzerine anlamlı etkileri olup olmadığı konusunda ilgili alan yazında çok sayıda bulgu ya da yoruma rastlanılamamaktadır. Bu durumun resim sanat dalına ilişkin bazı bulguların mevcut olmasıyla bir biçimde karşılandığ 1 söylenebilir ancak, özellikle müzik eğitimi açısından bu alan araştırmacılarının da vurguladığı gibi yeterince çalışma bulgusu olmadığ 1 gözlemlenmektedir. Diğer taraftan ilgili literatürde, müzik ve resim eğitim disiplinlerinin öğrencilerin yaratıcı düşünme becerileri üzerine anlamlı etkisi konusunda da karşılaştırmalı bir çalışmanın olmadığı gözlemlenmektedir. Oysa sanat disiplinleri açısından bu durum oldukça önemlidir. Dolayısıyla bu çalışmanın konusu; sanatın önemli disiplinlerinden olan Müzik ve Resim (Görsel Sanatlar) Eğitiminin bu alanlarda öğrenim gören öğrencilerin yaratıcı düşünme becerileri üzerine etkilerini Müzik Eğitimi ağırlıklı olarak incelemektir. Buna göre araştırma soruları da Müzik Eğitimi ağırlıklı olarak öğrencilerin yaratıcı düşünme becerilerinin geliştirilmesinde hangi disiplinin daha etkin olduğunu belirlemeye yönelik olarak oluşturulmuştur.

\section{Araştırmanın Amacı}

$\mathrm{Bu}$ amaçla, güzel sanatlar lisesinin 12. Sınıfına devam eden müzik öğrencileri ile 12. Sınıfına devam eden resim öğrencileri yaratıcı düşünme becerileri açısından karşılaştırılmıştır. Böylelikle, müzik ve resim sanat dallarında öğrenimlerine devam eden son sınıf öğrencileri karşılaştırılarak, hangi sanat dalının öğrencilerin yaratıcı düşünme becerilerinin gelişiminde daha etkili olup olmadığının ortaya konması amaçlanmıştır. Diğer taraftan bu kez, müzik eğitiminin öğrencilerin yaratıcı düşünme becerileri üzerine etkilerini belirlemek için, güzel sanatlar lisesinin bu sanat dalında 9. Sınıf ve 12. Sınıfa devam eden öğrencileri yaratıcı düşünme becerileri açısından karşılaştırılmıştır. Böylelikle, Müzik Eğitimi ağırlıklı olarak, bu sanat disiplini öğrencilerin yaratıcı düşünme becerilerine olan etkisi açısından müzik eğitimine devam eden ilk ve son sınıf öğrencileri karşılaştırılarak belirlenmeye çalışılmıştır.

\section{Yöntem}

$\mathrm{Bu}$ çalışma, nedensel karşılaştırma (causal comparative) ve kesitsel (cross-sectional) olmak üzere iki araştırma desenini içermektedir. İlk desende 12. Sınıf müzik öğrencileri ile 12. Sınıf resim öğrencileri sanat eğitiminde farklı disiplinler olarak yaratıcı düşünme beceri puanları açısından karşılaştırılmıştır. İkinci desende ise, kesitsel olarak müzik eğitiminde belli gelişmişlik evrelerini temsil ettiği varsayılan 9. ve 12. Sınıf müzik öğrencileri kendi içlerinde yaratıcı düşünme beceri puanları açısından karşılaştırılmıştır. Çalışmadan elde edilen verilerin istatistik çözümlemesinde Kovaryans Analizi tekniği kullanılmıştır. Araştırmanın katılımcıları; Müzik 12. Sınıf (13 öğrenci) ve 9. Sınıfa (17 öğrenci) devam eden 33 öğrenci ile birlikte Resim Eğitimi 12. Sınıfına devam eden 22 öğrenci olmak üzere toplam 52 öğrencidir. Araştırmada öğrencilerin yaratıcı düşünme 
The Role Of Art Educatıon On The Creatıve Thınkıng Skılls Of Students In Musıc...

becerileri Torrance Yaratıı Düşünme Testi (TYDT) Şekilsel formları kullanılarak belirlenmeye çalışılmıştır.

\section{Bulgular, Tartışma ve Sonuçlar}

Araştırma sonuçları ile ilgili istatistiksel veri analizinin sonuçlarına göre, 12. Sınıf Müzik ve Resim Eğitimine devam eden öğrencilerin yaratıcı düşünme puanları arasında genel olarak anlamlı bir farklılık bulunmamıştır. Buna karşın, yaratıcı düşünme alt boyutlarından Orijinallikte Müzik Eğitimine devam eden 12. Sınıf öğrencileri Resim Eğitimine devam eden 12. Sınıf öğrencilerine göre anlamlı olarak farklı ve yüksek puanlara sahipken, Erken Kapamaya Direnç alt boyutunda da 12. Sınıf Resim Eğitimine devam eden öğrenciler anlamlı olarak yüksek puanlara sahip oldukları belirlenmişsir.

Diğer taraftan, Müzik Eğitimine devam eden 12. Sınıf öğrencileri ile 9. Sınıf müzik öğrencileri arasında yapılan karşılaşıırmada ise, bu iki öğrenci grubu arasında yaratıcı düşünme becerileri açısından anlamlı bir farklılık bulunmamıştır. Buna karşın, 12. Sınıf müzik öğrencileri 9. Sınıf müzik öğrencilerine göre yaratıcı düşünme Orijinallikte ve Yaratıcı Güçler alt boyutlarında anlamlı derecede yüksek puanlara sahip oldukları bulunmuştur.

Buna göre, sanat eğitimi disiplinleri olarak müzik ve resim eğitimlerinin öğrencilerin yaratıcı düşünme becerilerini olumlu yönde geliştirme açısından birbirlerinden ayrıcalıklı bir konumda olmadıkları söylenebilir. Diğer taraftan, yaratıcı düşünme alt boyutları açısından sonuçlar değiștiği için aynı yorumda bulunmak zor görünmektedir. Çünkü müzik 12. Sınıf öğrencileri Orijinallikte hem resim 12. Sınıf öğrencilerinden hem de kendi disiplinleri içinde 9. Sınıf müzik öğrencilerinden olumlu gelişme göstererek, anlamlı olarak farklılaştıkları bulunmuştur. Bu sonuç, Müzik Eğitiminin ana etkisi olarak öğrencilerin orijinallik (yenilikçilik) becerilerinin gelișmesinde oldukça etkili bir konumda olduğunu göstermesi bakımından önemlidir. Bu durum alan uzmanlarınca da paylaşıldığı üzere birçok nedene dayanabilir ancak, bu çalışmada varılan en olası nedenler arasında doğaçlama müzik alıştırmaları gelmektedir. Buna göre, özellikle bir müzik aletini çalma konusunda oldukça yetkin bir konuma gelen üst sınıfa devam eden öğrencilerin (Müzik 12. Sınıf öğrencileri) başka müzik aletleri ya da bildikleri melodileri farklı çalma isteğinden kaynaklanan doğaçlamaya yatkınlıklarıyla alt sınıf öğrencilerine göre daha çok firsat bulmaları söylenebilir. Bu durum müzik öğrencilerinin doğaçlama yapma eğilimlerini olumlu yönde etkileyeceği ve bu etkinin sonunda yeni bir şeylerin (melodi ya da çalma tekniği gibi) keşfedilmesiyle birlikte öğrencilerin Orijinallik becerilerinin anlamlı olarak gelişmesiyle sonuçlanabileceği söylenebilir. 